\title{
PENGARUH LATIHAN SIRKUIT DENGAN INTERVAL ISTIRAHAT TETAP DAN MENURUN TERHADAP KOMPOSISI TUBUH PEMAIN BOLA VOLI PUTRI
}

\author{
Fatkurahman Arjuna ${ }^{1}$ \\ ${ }^{1}$ Ilmu Keolahragaan, Fakultas Ilmu Keolahragaan, Universitas Negeri Yogyakarta \\ Jl. Colombo No. 1, Karangmalang, Depok, Sleman, Daerah Istimewa Yogyakarta, Indonesia. \\ arjuna@uny.ac.id
}

\begin{abstract}
Abstrak
Penelitian ini bertujuan untuk mengkaji dan menguji ada tidaknya perbedaan pengaruh jenis latihan sirkuit dengan interval istirahat tetap dan menurun terhadap komposisi tubuh pemain bola voli putri. Penelitian ini merupakan penelitian kuantitatif dengan Metode eksperimen semu (quasi eksperimen). Analisis data menggunakan analisis kuantitatif kelompok perlakuan menggunakan jenis latihan sirkuit dengan interval istirahat tetap dan menurun terhadap IMT (indeks masa tubuh dan lemak tubuh). Subjek dalam penelitian ini pemain bola voli baja 78 yang berjumlah 36 orang. Hasil pengukuran menunjukkan bahwa perlakuan latihan sirkuit interval dengan istirahat tetap dan kontrol sama-sama tidak menunjukkan peningkatan yang berarti antara pretest dan posttest sedangkan pada pengukuran IMT perlakuan latihan sirkuit dengan interval menurun menunjukkan peningkatan yang berarti.

Kata Kunci: Latihan sirkuit, interval, komposisi tubuh, bola voli.

\section{EFFECT OF CIRCUIT TRAINING WITH FIXED AND DECREASED RESTING INTERVAL ON BODY COMPOSITION OF FEMALE VOLLEYBALL PLAYERS}

\begin{abstract}
This study aims to examine and test whether there are differences in the effect of circuit training types with fixed and decreased resting interval on the body composition of female volleyball players. This research is a quantitative research with quasi-experimental method. The data analysis used quantitative analysis of the treatment group using a type of circuit training with fixed and decreased rest intervals for BMI (body mass index and body fat). Subjects in this study were "baja 78 " volleyball players totaling 36 people. The measurement results showed that the treatment of interval training circuits with constant rest and control equally did not show a significant increase between pretest and posttest whereas the measurement of BMI treatment circuit training with a decreased interval showed a significant increase. Keywords: Circuit training, intervals, body composition, volleyball.
\end{abstract}

\section{PENDAHULUAN}

Bola voli merupakan salah satu cabang olahraga yang cukup banyak diminati bahkan diberbagai negara termasuk Indonesia. Federation Internasionale de Volleyball (FIVB) merupakan induk internasional bola voli dan bola voli pantai yang berpusat di Swiss. Jonathan C. Reeser \& Roald Bahr, (2003: 1-2) menyatakan bahwa lebih dari 800 juta diseluruh dunia telah memainkan permainan bola voli, ini membuktikan bahwa permainan bola voli cukup digemari disemua kalangan.

Franciele Marques Vanderlei, et al (2013: 1) dalam penelitianya menyebutkan cidera pada pemain bola voli dari subjek 522 ditemukan frekuensi cidera sebanyak $19 \%$ dengan rincian pergelangan kaki 36,5\% dan $75 \%$ terlepas dari karakteristik pribadi dalam latihan. Sedangkan Carazzato JG, et al (1992: 745) melakukan penelitian tentang cidera utama pada pemain bola voli yunior dengan hasil cidera lutut $(26,6 \%)$, pergelangan kaki $(19,52 \%)$, tulang belakang 
$(13,44 \%)$, cidera pada tangan $(13,3 \%)$ dan pada bahu (7,9 \%). Agel, et al (2007: 295) mengemukakan bahwa $55 \%$ cidera yang terjadi pada pemain bola voli terjadi di bagian bawah anggota badan dengan dominasi pada pergelangan kaki (ligamentous sprains ankle) dan $20 \%$ di bagian tungkai atas (upper limbs).

Olahraga bola voli sangat rawan terhadap cidera karena karakter permainan ini adalah melompat untuk melakukan serangan maupun halauan serangan lawan. Sheppard et al (2007: 267) pada kejuaraan internasional selama reli berlangsung 12 detik rata-rata pemain melakukan satu gerakan melompat untuk pemain depan melakukan gerakan lompatan sebanyak 3-4 kali lompatan. Komposisi tubuh sangat berperan dalam permainan ini, komposisi tubuh merupakan susunan tubuh yang digambarkan sebagai dua komponen yaitu indeks masa tubuh dan lemak tubuh. Sebagai contoh pemain bola voli dengan kondisi obesitas atau kelebihan berat badan tentu akan menggangu performa bahkan akan rawan terhadap cidera, obesitas merupakan keadaan yang menunjukkan ketidak seimbangan antara tinggi dan berat badan akibat jaringan lemak dalam tubuh. Bahkan obesitas atau kelebihan berat badan memiliki banyak resiko penyakit seperti hipertensi, jantung koroner, diabetes mellitus dan masih banyak yang lainnya.

Latihan yang salah juga dapat menyebabkan obesitas karena energi yang dikeluarkan tidak sebanding dengan asupan makanan. Begitu pula dengan kekurangan nutrisi atau nutrisinya di bawah standar rata rata dapat dikatakan gizi buruk dapat berpengaruh terhadap performa penampilan. Tubuh tidak akan mensuport penampilan dalam bermain bola voli karena sumber energi yang diperlukan tidak didapatkan, maka dari itu perlu adanya keseimbangan komposisi tubuh terutama pemain bola voli untuk meningkatkan performa penampilan saat pertandingan. Wanita lebih mudah gemuk dari pada pria, wanita memiliki komposisi tubuh yang berbeda dan lemak lebih banyak jumlahnya. Pada wanita normal total lemak $20-25 \%$ dari berat badannya sedangkan pria rata rata $10-15 \%$ lemak. Wanita memiliki hormon estrogen yang dimiliki wanita juga mempengaruhi dalam menyimpan lemak, maka dari itu penting bagi pemain bola voli terutama wanita latihan fisik untuk menjaga kondisi fisiknya terutama komposisi tubuh.

Kondisi fisik dalam olahraga terutama pemain bola voli sebagai fondasi untuk belajar teknik, strategi dan mental. Selain itu dengan kondisi fisik yang baik dapat mencegah terjadinya cidera (mengurangi resiko cidera), mampu menerima latihan yang relatif berat, dapat mempertahankan postur tubuh, berat badan serta dapat meningkatkan rasa percaya diri. Mansur (2007: 4) manfaat bagi pemain bola voli dapat meningkatkan prestasi, tidak mudah lelah walaupun pertandingan yang relatif lama, mudah pulih asal setelah latihan, mengurangi nyeri otot, mampu berlatih dengan baik dengan waktu yang relatif lama, lebih percaya diri serta lebih enjoy dalam bermain.

Metode latihan sirkuit menjadi pilihan utama dalam meningkatkan performa pemain bola voli karena memiliki banyak keunggulan diantaranya secara efektif mengurangi waktu yang dikhususkan untuk pelatihan dengan volume pelatihan yang memadai untuk dicapai, melibatkan berbagai otot tubuh dalam satu waktu latihan, evektif dan efisien dalam mencapai target latihan. Latihan sirkuit juga merupakan latihan dengan dominan kapasitas aerobik sehingga dapat efektif apabila diterapkan terhadap komposisi tubuh.

\section{Bola voli}

Jonathan C. Reeser dan Roald Bahr (2003: 1) Permainan bola voli di buat oleh seorang instruktur pendidikan jasmani (director of physical education) yang bernama William G. Morgan di YMCI Hokyoke, Massachusetts, Amerika Serikat dengan nama Mintonette. Permainan ini mengadopsi dari 4 macam karakter olahraga yang terdiri dari bola basket, baseball, tenis dan bola tanggan digabung menjadi satu. Induk organisasi internasional olahraga bola voli dan bola voli pantai adalah FIVB (federation internasionale de volleyball) yang berkantor pusat di Lausanne Swiss. Induk organisasi bola voli di Indonesia dinaungi oleh PBSI 
(Persatuan Bola Voli Seluruh Indonesia). The international governing body for the sport menyatakan bahwa lebih dari 500 juta orang diseluruh dunia bermain bola voli.

USA Volleyball (2017: 18) tujuan dari permainan bola voli adalah mendapatkan poin dengan cara sedemikian rupa menempatkan bola ke area lapangan lawan sehingga lawan tidak bisa mengembalikanya. Bola voli memiliki peraturan dalam keberagaman gerakan dalam peraturanya tidak boleh memegang bola atau melempar bola hal tersebut berkaitan dengan teknik-teknik yang melibatkan gerakan passing, smash, service dan blocking. Permainan ini juga menuntut keberagaman gerakan dalam melakukan teknik, keterampilan, daya tahan, konsentrasi dan cepat dalam pengambilan keputusan.

\section{Latihan sirkuit}

Bompa (1994: 3) Training is usually defined as systematic process of long duration repetitive, progressive exercises, having the ultimate goal of improfing athletic performance. Latihan merupakan suatu proses yang sistematis dapat berubah, berkelanjutan serta bertujuan secara maksimal untuk memperbaiki performa atlet. Keberhasilan untuk mencapai latihan yang optimal ditentukan oleh kualitas latihan itu sendiri yang meliputi: tujuan latihan, pemilihan latihan, penggunaan sarana latihan atau dosis latihan yang dijabarkan dalam konsep FIT (frequency, intensity dan time). Menurut Emmanuel Frimpong et al, (2004: 170) latihan sirkuit merupakan latihan yang dilakukan secara berurutan dengan jumlah stasiun, penggulangan dan durasi set yang telah ditetapkan. Latihan ini dapat menghasilkan perbaikan kekuatan otot, kecepatan, daya tahan dan aman dengan cara mengorganisir pelatihan ke dalam suatu sirkuit dengan serangkaian stasiun kerja. Latihan sirkuit juga merupakan latihan dengan pendekatan untuk pelatihan kapasitas aerobik dalam olahraga. Latihan sirkuit juga efektif dalam penurunan lemak tubuh, seperti penelitian yang telah dilakukan oleh Hakim \& Prasetyo, Y (2018). Dipaparkan bahwa circuit bodyweight training memberikan pengaruh terhadap penurunan persentase lemak yang ditunjukkan pada hasil uji-t pada persentase lemak diperoleh nilai sig 0,036 (Hakim \& Prasetyo, Y, 2018). Diperkuat lagi oleh penelitian yang dilakuakan oleh Purwanto \& Nasrulloh, A (2017) bahwa metode circuit weight training efektif untuk menurunkan berat badan dan prosentase lemak.

Daniel Mayorga (2013: 153) pelatihan sirkuit memiliki keunggulan secara efektif mengurangi waktu yang dikhususkan untuk pelatihan dengan volume pelatihan yang memadai untuk dicapai. Selain itu memungkinkan waktu keterlibatan motor yang lebih besar yang merupakan persyaratan yang sangat penting bagi keberhasilan program yang akan dicapai. Brett Klika, C.S (2013: 8-9) Bentuk-bentuk modern dari latihan sirkuit dikembangkan oleh R.E.Morgan dan G.T. Anderson pada tahun 1953 di University of Leeds di Inggris. Latihan sirkuit dilakukan dengan $9-12$ protokol latihan di mana, atlet melakukan latihan pada intensitas (sekitar $40 \%$ hingga $60 \%$ dari $1 \mathrm{RM}$ ) untuk jumlah pengulangan atau jumlah waktu tertentu. Klika, B., \& Jordan, C. (2013: 10-11) protokoler dalam pelatihan sirkuit antara 9-12 stasiun namun tidak ada jumlah stasiun yang ideal. Catatan penting untuk program umum semua otot digunakan pada intensitas yang sesuai selama sesi latihan dan jumlah stasiun latihan akan mempengaruhi total waktu latihan dan hasilnya. Bompa (2015: 232) menjelaskan bahwa ada tiga macam program latihan sirkuit, yaitu: sirkuit A menggunakan berat badan, sirkuit B menggunakan berat baadan atau kombinasi dari dua sirkuit mini, dan sirkuit $\mathrm{C}$ menggunakan barbell dan bola medicine. 


\section{Interval}

Recovery dalam istilahnya memiliki makna pemberian waktu istirahat, yang hampir selalu dikaitkan dengan interval. Recovery diberikan saat olahraga pada waktu istirahat antar set atau antar repetisi (ulangan). Menurut Emral (2017) recovery terdiri dari dua bentuk yang dapat dilakukan atlet selama latihan maupun saat pertandingan, yaitu recovery aktif, dan recovery pasif. Recovery aktif diartikan sebagai proses pemulihan dengan menggunakan gerakan intensitas ringan. Sedangkan recovery pasif adalah proses pemulihan dengan menggunakan gerakan yang sangat sedikit yang hampir tidak melakukan gerakan. Recovery atau pemulihan mempunyai kapasitas penting dalam isi ulang tenaga untuk melakukan aktivitas kembali. Apabila kebutuhan tersebut tidak terpenuhi maka atlet akan lebih berpotensi mengalami cedera. Recovery terjadi dalam beberapa tahap yang berbeda-beda: inter exercise, post exercise recovery dan long term recovery.

Menurut Bompa (2015: 67) Recovery adalah proses yang berhubungan langsung dengan beban latihan yang digunakan. Kurva pemulihan yang mewakili kemampuan tubuh untuk mencapai homeostasis tidak linear. Dinamika kurva pemulihan dibagi menjadi tiga tahap yaitu tahap pertama proses pemulihan 70 persen, tahap kedua 20 persen dan tahap ketiga 10 persen. Interval waktu untuk pemulihan tergantung pada keberadaan sistem energi. Waktu pemulihan setelah proses latihan dapat dilihat pada Tabel berikut ini:

Tabel 1. Waktu Pemulihan (Recovery)

\begin{tabular}{|l|l|}
\hline \multicolumn{1}{|c|}{ Proses Pemulihan } & \multicolumn{1}{c|}{ Waktu Pemulihan } \\
\hline Pemulihan ATP-CP & $2-8$ menit \\
\hline Pemulihan glikogen otot: & $10-48$ jam \\
Setelah latihan panjang & $5-24$ jam \\
Setelah latihan Intermittent & \\
\hline Penghapusan asam laktat dari otot dan darah: & 30 menit -1 jam \\
Pemulihan aktif & $1-2$ jam \\
Pemulihan pasif & Sumb \\
\hline
\end{tabular}

(Sumber Bompa, 2015: 67)

\section{Komposisi tubuh}

\section{a. IMT (Indek Massa Tubuh)}

Indeks masa tubuh merupakan rumus matematis yang dinyatakan sebagai berat badan di bagi dengan tinggi badan. Berat badan dalam satuan kilogram $(\mathrm{kg})$ dan tinggi badan kuadrat dalam meter $(\mathrm{m})$. Metode IMT merupakan metode yang murah, mudah dan sederhana berfungsi untuk menilai status gizi pada seseorang indifidu, akan tetapi tidak dapat mengukur langsung lemak pada tubuh. Penilaian dan pengukuran IMT erat hubunganya dengan status gizi baik kekurangan maupun kelebihan. Penggunaan rumus IMT diterapkan untuk seseorang yang berusia sekitar 19 tahun hingga 70 tahun, bukan untuk ibu hamil dan menyusui serta atlet profesional. Untuk rumus IMT pada anak berbeda dengan rumus IMT pada orang dewasa, pada anak anak disesuikan dengan umur dan jenis kelamin anak dikarenakan anak laki laki dengan anak perempuan memiliki kadar lemak tubuh yang berbeda.

$$
\text { Rumus IMT }=\frac{\text { Berat badan }(\mathrm{Kg})}{\text { Tinggi Badan }(\mathrm{m})^{2}}
$$

Komponen IMT terdiri dari tinggi badan dan berat badan, untuk tinggi badan diukur dengan keadaan berdiri tegak lurus tanpa alas kaki, kedua tangan dirapatkan ke badan, punggung menempel pada dinding dan pandangan lurus ke depan. Berat badan diukur 
menggunakan timbangan badan. Timbangan badan dikalibrasi pada angka 0 sebagai permilaan dan memiliki ketelitian $0,1 \mathrm{~kg}$.

\section{b. Lemak}

Lemak merupakan senyawa molekul besar serta terbentuk dari molekul yang lebih kecil melalui reaksi dehidrasi, lemak tersusun dari dua jenis molekul yang lebih kecil yaitu asam lemak dan gliserol. Lemak apabila terlalu banyak dalam tubuh dapat menyebabkan berbagai penyakit dalam tubuh diantaranya obesitas, kerusakan dinding arteri, kolesterol tinggi dan yang lainya.

Dokter spesialis kedokteran olahraga dr. Zaini K Saragih, SpKO menjelaskan bahwa orang yang memiliki obesitas tidak diperkenankan olahraga yang mengandung gerakan melompat, menurut Zaini pada fase mendarat ini yang berbahaya pada saat mendarat kaki menumpu empat kali berat badan dan akan membahayakan bebrapa organ, seperti sendi, lutut dan otot otot. Bola voli sendiri merupakan olahraga dengan gerakan inti melompat untuk memperoleh point seperti gerakan melompat smash, melakukan bolok bakan pada saat servis.

\section{METODE}

Penelitian ini merupakan penelitian kuantitatif dengan metode eksperimen (quasi eksperiment). Subyek dalam penelitian ini adalah pemain bola voli putri baja 78 di Kabupaten Bantul berjumlah 36 orang. Dengan kriteria sebagai berikut: berjenis kelamin perempuan, umur 16-20 tahun, sehat jasmani dan rohani, atlet voli baja 78 yang sudah berlatih minimal 1 tahun dan mau dijadikan subjek penelitian. Penelitian ini dilakukan selama dua bulan tepatnya pada bulan Juli - September tahun 2018. Pelaksanaan treatment dilakukan sebanyak 24 kali dengan frekuensi tiga kali seminggu dan dilakukan secara berselang bertempat di Hal Bola Voli Pemda Bantul dan dilapangan DPRD Bantul.

\section{HASIL DAN PEMBAHASAN HASIL}

Program latihan yang diterapkan terhadap komposisi tubuh pemain bola voli putri menggunakan metode circuit training dengan interval istirahat dan tetap. Berikut program latihanya:

Tabel 1. Program Circuit Training

\begin{tabular}{|l|l|}
\hline \multicolumn{1}{|c|}{ Keterangan } & \multicolumn{1}{c|}{ Circuit Training } \\
\hline Lama Latihan & 8 minggu \\
\hline Frekuensi & 3 kali per minggu \\
\hline Jumlah Sirkuit & $\begin{array}{l}\text { 9 stasiun (shuttel run, half squat jump, squat trust, jumping jack, frog } \\
\text { jump, step up, side jump, bench jump, dan high jump) }\end{array}$ \\
\hline Waktu Tiap Sirkuit & 10 menit - 20 menit \\
\hline Jumlah Waktu & $30-45$ menit \\
\hline Beban & $60-80 \%$ dari RM (Repetisi Maksimal) \\
\hline Repetisi & $15-20$ kali \\
\hline $\begin{array}{l}\text { Interval Istirahat Tiap } \\
\text { Stasiun }\end{array}$ & $\begin{array}{l}45 \text { detik untuk interval tetap dan 10 detik untuk interval menurun, } \\
\text { diawali dari 80 detik untuk stasiun satu ke stasiun berikutnya }\end{array}$ \\
\hline Total Istirahat & 360 detik atau selama 6 Menit \\
\hline
\end{tabular}

Komposisi tubuh merupakan susunan tubuh yang digambarkan oleh dua komponen yang terdiri dari indek masa tubuh dan lemak tubuh.

a. IMT (Indeks Massa Tubuh) 
Pada penelitian ini pengukuran indeks massa tubuh (IMT) mengunakan data anthropometri meliputi berat badan $(\mathrm{kg})$ dengan tinggi badan $(\mathrm{m})$ pada saat pretest dan posttest. Pengukuran dilakukan untuk mengetahui indeks massa tubuh yaitu dengan cara membagi berat badan dengan kuadran tinggi badan hasil perhitungan tersebut dikasifikasikan sesuai dengan norma kategori ambang batas IMT sesuai dengan jenis kelamin dan kategori usia masing masing subyek khususnya orang Indonesia. Hasil kategorisasi IMT pemain bola voli putri dijabarkan dalam tabel berikut:

Tabel 2. Hasil Pengukuran IMT

\begin{tabular}{|c|c|c|c|c|}
\hline \multirow{2}{*}{ Kategori IMT } & \multicolumn{2}{|c|}{ Pretest } & \multicolumn{2}{c|}{ Posttest } \\
\cline { 2 - 5 } & Jumlah & Persentase & Jumlah & Persentase \\
\hline Gemuk + & 2 & $5,6 \%$ & 3 & $5,6 \%$ \\
Gemuk & 2 & $5,6 \%$ & 3 & $8,3 \%$ \\
Normal & 28 & $77,8 \%$ & 27 & $77,8 \%$ \\
Kurus & 3 & $8,3 \%$ & 2 & $5,6 \% \%$ \\
Sangat kurus & 1 & $2,8 \%$ & 1 & $2,8 \%$ \\
\hline & 36 & $100 \%$ & 36 & $100 \%$ \\
\hline
\end{tabular}

Berdasarkan hasil pengukuran pada tabel 2 dapat dijabarkan dari 36 orang atlet bola voli putri pada pretest terdapat 2 orang subjek $(5,6 \%)$ memiliki IMT pada kategori gemuk (+), 2 orang subjek $(5,6 \%)$ memiliki kategori IMT gemuk, 28 subjek $(77,8 \%)$ memiliki kategori IMT Normal, 3 orang subjek memiliki kategori IMT kurus dan 1 orang subjek $(2,8 \%)$ memiliki IMT pada kategori sangat kurus. Pada pengukuran posttest hasil yang didapat adalah 3 orang subjek (8,3\%) memiliki IMT dengan kategori gemuk (+), 3 orang subjek $(8,3 \%)$ memiliki kategori IMT gemuk, 27 orang subjek $(75,0 \%)$ memiliki IMT pada kategori normal, 2 orang subjek $(5,6 \%)$ memiliki IMT pada kategori kurus dan 1 orang subjek $(2,8 \%)$ memiliki IMT pada kategori kurus sekali.

Kesimpulan pada hasil pengukuran baik pretest maupun posttest tidak menunjukkan perubahan yang signifikan dan dapat disimpulkan baik saat pretest maupun posttest mayoritas subjek penelitian memiliki IMT pada kategori normal. FAO atau WHO (2007) telah membuat rujukan untuk ambang batas IMT baik untuk ambang batas baik laki laki maupun perempuan. Untuk laki-laki ambang batas normal adalah 20,1 - 25,0 sedangkan untuk perempuan adalah $18,7-23,8$. Selanjutnya dilakukan perhitungan rerata (mean) antara pretest dengan posttest antar subjek perlakuan latihan sirkuit dengan interval istirahat tetap menurun dan kontrol. Hasil perhitungan rerata (mean) IMT antara pretest dan posttest dapat dijabarkan dalam tabel berikut:

Tabel 3. Perbandingan Rerata IMT antar perlakuan.

\begin{tabular}{|l|c|c|c|}
\hline \multicolumn{1}{|c|}{ Perlakuan } & Pretest & Posttest & Selisih \\
\hline Kontrol & 21,6 & 21,9 & 0,28 \\
Istirahat tetap & 20,8 & 21,2 & 0,37 \\
Istirahat menurun & 23,1 & 24,3 & 1,18 \\
\hline
\end{tabular}

Pada tabel diatas dapat dijabarkan bahwa perlakuan latihan sirkuit interval dengan istirahat tetap dan kontrol sama-sama tidak menunjukkan peningkatan yang berarti antara pretest dan posttest sedangkan pada pengukuran IMT perlakuan latihan sirkuit dengan interval menurun menunjukkan peningkatan yang berarti.

b. Lemak

Pada penelitian ini presentase lemak diukur menggunakan alat body fat analyzer. Hasil pengukuran kemudian dikonfersikan pada norma status lemak tubuh sesuai dengan 
jenis kelamin dan kategori usia masing masing subjek. Hasil dari pengukuran lemak tubuh dapat dijabarkan pada tabel berikut:

Tabel 4. Hasil Pengukuran Lemak Tubuh

\begin{tabular}{|c|c|c|c|c|}
\hline \multirow{2}{*}{ Kategori } & \multicolumn{2}{|c|}{ Pretest } & \multicolumn{2}{c|}{ Posttest } \\
\cline { 2 - 5 } Persentase lemak & Jumlah & Persentase & Jumlah & Persentase \\
\hline Berlebih & 0 & $0,0 \%$ & 0 & $0,0 \%$ \\
Normal & 35 & $97 \%$ & 35 & $97 \%$ \\
Kurang & 1 & $2,8 \%$ & 1 & $2,8 \%$ \\
\hline & 36 & $100,0 \%$ & 36 & $100,0 \%$ \\
\hline
\end{tabular}

Dapat disimpulkan dari tabel di atas bahwa baik pada pretest maupun posttest mayoritas subyek dalam penelitian memiliki presentase lemak tubuh pada kategori normal dan hasil pengukuran presentase lemak tubuh antara pretest dan posttest tidak menunjukkan perubahan yang berarti. Hasil perhitungan rerata (mean) persentase lemak tubuh antara pretest dan posttest antar perlakuan sebagai berikut:

Tabel 5. Perbandingan Rerata Persentase Lemak Tubuh antar Perlakuan

\begin{tabular}{|l|c|c|c|}
\hline \multicolumn{1}{|c|}{ Perlakuan } & Pretest & Posttest & Selisih \\
\hline Kontrol & 25,4 & 24,8 & $-0,62$ \\
Istirahat Tetap & 25,8 & 26,7 & 0,83 \\
Istirahat menurun & 23,8 & 24,1 & 0,32 \\
\hline
\end{tabular}

Dapat dilihat pada tabel di atas dari hasil perbandingan pengukuran persentase lemak tubuh bahwa perlakuan latihan mengunakan sirkuit interval istirahat tetap dan menurun sama-sama menunjukkan peningkatan antara pretest dan posttest dan pada pengukuran persentase lemak tubuh perlakuan dan kontrol antara pretest dan posttest menunjukkan penurunan yang berarti.

\section{PEMBAHASAN}

Hasil pengukuran IMT baik pretest maupun posttest tidak menunjukkan perubahan yang signifikan, pada saat pretest maupun posttest mayoritas subjek penelitian memiliki IMT pada kategori normal dapat dilihat pada tabel di atas. Pada perlakuan latihan sirkuit interval dengan istirahat tetap dan kontrol sama-sama tidak menunjukkan peningkatan yang berarti antara pretest dan posttest sedangkan pada pengukuran IMT perlakuan latihan sirkuit dengan interval menurun menunjukkan peningkatan. Dapat dijabarkan bahwa IMT sangat berhubungan dan dipengaruhi oleh usia, jenis kelamin, genetik, pola makan dan aktivitas fisik. Aktivitas fisik yang dimaksud yaitu disesuaikan dengan kebutuhan pada sistem energi yang dibutuhkan, dengan latihan fisik dengan metode sirkuit training dengan interval menurun dapat meningkatkan intensitas latihan. Dengan intensitas latihan yang meningkat akan mempengaruhi IMT tubuh.

Pada pengukuran lemak tubuh dapat dilihat bahwa baik pada saat pretest maupun posttest mayoritas subyek dalam penelitian memiliki presentase lemak tubuh pada kategori normal dan hasil pengukuran presentase lemak tubuh antara pretest dan posttest tidak menunjukkan perubahan yang berarti. Pada tabel dapat disimpulkan hasil perbandingan pengukuran persentase lemak tubuh bahwa perlakuan latihan mengunakan sirkuit interval istirahat tetap dan menurun sama-sama menunjukkan peningkatan antara pretest dan posttest dan pada pengukuran persentase lemak tubuh perlakuan dan kontrol antara pretest dan posttest menunjukkan penurunan yang berarti. 
Dalam penelitian ini, peneliti memiliki keterbatasan yaitu tidak dapat mengontrol pola istirahat dan pola makan subjek dan itu tentu saja akan mempengaruhi kadar lemak tubuh. Peneliti juga memiliki keterbatasan dalam memantau subjek dalam latihan maupun aktivitas tambahan diluar program latihan. Aktivitas fisik yagn dilakukan secara rutin akan dapat mempengaruhi kadar lemak dalam tubuh seperti aktivitas fisik mengunakan metode latihan sirkuit dengan intensitas tetap maupun menurun. Aktivitas fisik yang dianjurkan oleh dokter ahli kesehatan adalah aktifitas yang dilakukan dengan intersitas sedang atau bertenaga selama 30 menit untuk setiap harinya dalam perminggu untuk program latihan yang bertujuan menurunkan kadar lemak dan IMT.

\section{SIMPULAN}

Berdasarkan hasil penelitian pengaruh latihan sirkuit dengan interval istirahat tetap dan menurun terhadap komposisi tubuh pemain bola voli putri dapat disimpulkan sebagai berikut:

1. Hasil pengukuran baik pretest maupun posttest tidak menunjukkan perubahan yang signifikan dan dapat disimpulkan baik saat pretest maupun posttest mayoritas subjek penelitian memiliki IMT pada kategori normal, perlakuan latihan sirkuit interval dengan istirahat tetap dan kontrol sama sama tidak menunjukkan peningkatan yang berarti antara pretest dan posttest sedangkan pada pengukuran IMT perlakuan latihan sirkuit dengan interval menurun menunjukkan peningkatan yang berarti.

2. pada pretest maupun posttest mayoritas subyek dalam penelitian memiliki presentase lemak tubuh pada kategori normal dan hasil pengukuran presentase lemak tubuh antara pretest dan posttest tidak menunjukkan perubahan yang berarti, perlakuan latihan mengunakan sirkuit interval istirahat tetap dan menurun sama sama menunjukkan peningkatan antara pretest dan posttest dan pada pengukuran persentase lemak tubuh perlakuan dan kontrol antara pretest dan posttest menunjukkan penurunan yang berarti.

\section{DAFTAR PUSTAKA}

Bompa T.O. (1994). Theory and Methodology of Training, (4 ${ }^{\text {th }}$ edition). Dubuque. Lowa: Kendal/Hunt Publishing Company.

Bompa, T.O. and Buzzichelli, C. (2015). Periodization Training for Sport. United States: Human Kinetics.

Brett Klika, C.S.C.S., B.S. and Chris Jordan, M.S., C.S.C.S., (2013). High-Intensity Circuit Training Using Body Weight: Maximum Results With Minimal Investment. ACSM's HEALTH \& FITNESS JOURNAL Vol 17 No. 3 Hal 8-13

Carazzato JG, Campos LAN, Carazzato SG. (1992). Incidência de lesões traumáticas em atletas competitivos de dez tipos de modalidades esportivas. Rev Bras Ortop 1992, 27:745-758.

Daniel Mayorga (2013). Effects of a Circuit Training Program on Muscular and Cardiovascular Endurance and their Maintenance in Schoolchildren. Journal of Human Kinetics Volume 37/2013 hal 153-160

Emmanuel Frimpong, Olajide Ayinla Olawale, Daniel Ansong, Antwi, Charles AntwiBoasiako, and Bartholomew Dzudzor. (2014). Task-Oriented Circuit Training Improves Ambulatory Functions in Acute Stroke: a Randomized Controlled Trial. Journal of Medicine and Medical Sciences Vol. 5(8) pp. 169-175

Emral (2017) Pengatar Teori dan Metodologi Pelatihan Fisik. Jakarta: Kencana.

Franciele Marques Vanderlei, et. al (2013). Characteristics and contributing factors related to sports injuries in young volleyball players. BMC Research Notes 2013, 6:415 
Hakim, A. A. \& Prasetyo, Y. (2018). Pengaruh Circuit Bodyweight Training terhadap Daya Tahan Jantung Paru dan Persentase Lemak. MEDIKORA. Vol 17, No 1 (2018): April. FIK UNY.

Jonathan C. Reeser and Roald Bahr (2003). Handbook of Sports Medicine and Science Volleyball. United Kingdom: Blackwell Science

Mansur (2007). Buku Pedoman Pelatihan Bolavoli Nasional. Yogyakarta: FIK UNY

Purwanto, P. \& Nasrulloh, A. (2017). Efektivitas Latihan Beban dengan Metode Circuit Weight Training dengan Super Set terhadap Penurunan Berat Badan dan Prosentase Lemak. MEDIKORA. Vol 16, No 1 (2017): April. FIK UNY.

Sheppard J, Newton R, McGuigan M. (2007) The effect of accentuated eccentric loadon jump kinetics in high-performance volleyball players. Int J Sports Sci Coach 2007a: 2: 267273.

USA Volleyball. (2017). 2017-19 Indoor Domestic Competition Regulations. FIVB: USA Volleyball. 